\title{
ANALYSIS OF TECHNICAL EQUIPMENT IN DAIRY FARMS
}

\author{
Andrzej Borusiewicz \\ Department of Agronomy, Academy of Agribusiness in Łomża \\ *Corresponding author: e-mail: andrzej.borusiewicz@wsa.edu.pl
}

\begin{tabular}{|c|c|}
\hline ARTICLE INFO & ABSTRACT \\
\hline $\begin{array}{l}\text { Article history: } \\
\text { Received: October } 2016 \\
\text { Received in the revised form: } \\
\text { December } 2016 \\
\text { Accepted: January } 2017 \\
\end{array}$ & \multirow{2}{*}{$\begin{array}{l}\text { The paper analyses technical equipment of the selected dairy farms. } \\
\text { Data from questionnaires carried out in } 96 \text { farms in } 2015 \text { constituted } \\
\text { a research material. Municipalities Lszewo-Borki in Mazowieckie } \\
\text { Voivodeship were covered by the survey. A survey questionnaire, } \\
\text { which consisted of two parts, was a research instrument. The first } \\
\text { concerned general information on a farm and its owner, and the other } \\
\text { consisted of eight questions on technical equipment used for breeding } \\
\text { dairy cows. The research allowed to determine that farmers assessed } \\
\text { the condition of their machinery park as average (50\%) or good } \\
\text { (40\%). One out of ten farmers claimed that the used machinery park in } \\
\text { a farm is in a bad condition. Majority of respondents have allotted } \\
\text { from PLN } 20 \text { to } 50 \text { thousand for investments related to enhancement } \\
\text { of a machinery park within the last } 5 \text { years. On the other hand, } \\
\text { a considerable part of farms allotted up to PLN } 20 \text { thousand for devel- } \\
\text { opment of a machinery park. The investigated group included also } \\
\text { farms, which allotted more than PLN } 500 \text { thousand for development } \\
\text { of a park. }\end{array}$} \\
\hline $\begin{array}{l}\text { Key words: } \\
\text { machines, } \\
\text { technical equipment, } \\
\text { dairy cows breeding }\end{array}$ & \\
\hline
\end{tabular}

\section{Introduction}

Mechanization and implemented innovations considerably facilitate the farmer's work and complex realization of various technological treatments in the plant and animal production which is carried out according to applicable agri-technical requirements and does not burden farms with the costs which are in excess of their ability to replace the owned machines and tractors (Banasiak, 2008). The employment size as well as the size of incurred inputs of operation depends on the agricultural type of a farm (Kocira and Kocira, 2010).

The mechanization costs come from the amount and value of farm equipment and current costs of its use. Maintenance costs of machines calculated into an assumed work unit (h, ha, t, item) are lower if the power output capacity of particular machines is more used, namely if they are more and more intensively used. Realization of this objective depends inter alia on an accurate and relevant selection of specialist machines adjusted to the production scale (Muzalewski, 2007). Farmers also use mechanization services offered by other farmers or specialized service providers (Kapela et al., 2011).

Fully rational selection of mechanization means for a farm should result in such a number and such performance of particular machines and devices that their capacity is optimally used (Jóźwik et al., 2012). This, consequently, caused better reduction of unit costs of 
machines and devices maintenance per a work, area and product unit (Parafiniuk, 2006; Cupiał, 2010; Cupiał, 2009). Computer specialist programs may assist a farmer in proper selection of devices (Marczuk, 2010; Borusiewicz and Kapela, 2013).

Introduction of devices which ensure good micro-climatic conditions, maintaining cleanness, proper living conditions, safety and protection of animal health, feeding, drinking causes a clear improvement of animal welfare (Romaniuk, 2005; Marczuk and Turski, 2009; Banasiak, 2008),which has a decisive impact on the production efficiency (Romaniuk et al., 2005).

Regardless the applied production system, the progress in agricultural engineering causes a considerable improvement of effectiveness of production inputs and a visible reduction of ecology losses. Improvement of mechanization means constructions enables also the increase of efficiency, reduction of unit energy inputs and due respect for environment (Michałek and Tomczyk, 2002; Auemhammer, 2003).

The more technically advanced is the equipment used in farms, the higher is also the risk of losses in case of unskilled, faulty operation or incorrect work organization (Pawlak, 2010).

\section{Objective, scope and methodology of research}

The objective of the research was analysis of technical equipment of a dairy farm. Data from questionnaires in 96 selected dairy farms in 2015 constituted the research material. Municipalities Lszewo-Borki in Mazowieckie Voivodeship were covered by the survey. A survey questionnaire, which consisted of two parts, was a research instrument. The first part concerned general information and its owner and the other consisted of eight questions concerning technical equipment used in dairy cows breeding.

In order to carry out evaluation, farms were divided on account of the surface area into four groups: below 15 ha, 15-20 ha, 21-30 ha and above 30 ha of agricultural land. The respondents were divided into five age groups: 18-25 years, 26-35 years, 36-45 years, and above 50 years. Additionally, a division was made on account of the education degree and experience in running a farm.

\section{Research results}

88 men (92\%) and 8 women (8\%) participated in the survey. People aged 26-35 (36\% of the total number of respondents) constituted the biggest group of respondents). On the other hand, the respondents who were aged $36-45$ constituted $28 \%$ of respondents. $12 \%$ of the respondents were aged 46-50. Respondents aged 18-25 (18\%) and above $50(6 \%)$ were the least numerous group. The majority of respondents obtained secondary education in agriculture (36\%), some of them obtained post-secondary education in agriculture (22\%), university agricultural education (16\%) and the vocational one (14\%). The remaining persons declared that they participated in an agricultural training and other education forms (6\%). The investigated group included farmers with small farms with the surface area below 15 ha (38\%) and 15-20 ha (32\%). Farmers with farms with the acreage of 21-30 ha constituted $20 \%$ of the investigated group. The least numerous group consisted of farmers with farm above 30 ha (10\%). The surface area of the smallest farm was 8 ha of the owned agri- 
Analysis of technical...

cultural land, the biggest one was 74 ha, the average surface area of the investigated farms was 13.5 ha. No significant relations between the size of a farm and farmer's education were not reported.

Persons who have run agricultural business for 11 and 20 years were the majority $36 \%$. Farmers who have been running a farm more than 20 years constituted the next group, namely $32 \%$. Among the respondents, there were also persons who have owned a farm between 6 and 10 years (24\%). The least numerous was a group of people who have owned a farm between 1 and 5 years (8\%). In all investigated farms, sheds were equipped with roof windows and curtains or fixed walls. Majority of respondents answered that there were 1 to 2 persons working in a farm (62\%). One third of the investigated farmers (32\%) indicated that there were 2 to 5 persons working in a farm. There were also people who declared that more than 5 people worked in a farm.

The questioned farmers indicated the most often that they have their own tractors with the power of 40-60 kW (46\%) and $60 \mathrm{~kW}$ and higher power (34\%). A part of the investigated farmers indicated also that they used tractors with the power of $25-40 \mathrm{~kW}(13 \%)$, $15-25 \mathrm{~kW}(4 \%)$ and up to $15 \mathrm{~kW}$ (3\%) - (Fig.1).

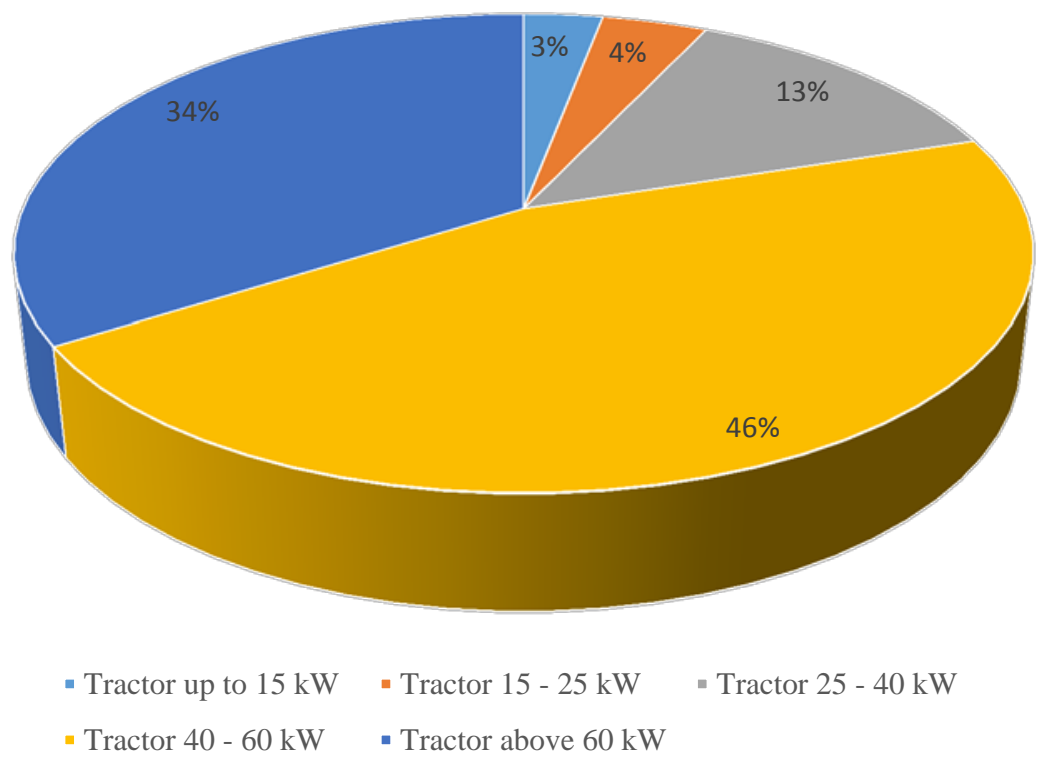

Figure 1. Power of owned tractors in farms

All surveyed farmers have farm trailers. Two third of the farms were equipped with the following machines: mowers (82\%), extracters for sewage (76\%), sprayers (76\%), mixtures of fodders $(70 \%)$ and fodder carts $(70 \%)$. The farms also had stubble units $(62 \%)$, manure spreaders (50\%), grain harvesters (38\%), disc harrows (36\%) and sprinklers (30\%). Less than one fourth of farms had front loaders (24\%), tedders (10\%) and septic tankers (7\%) (Fig. 2). 


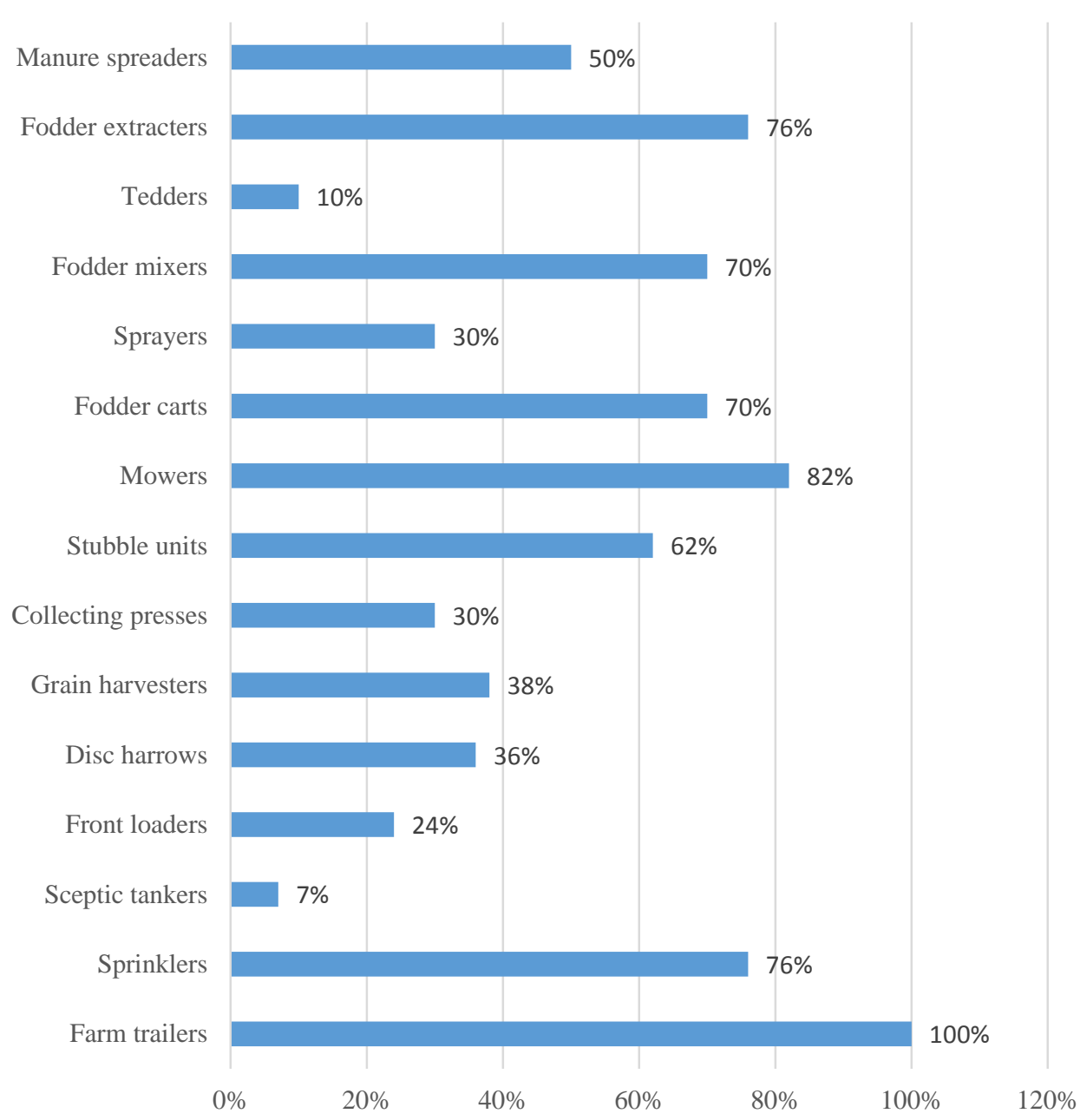

Figure 2. Type of owned farm tractors

Majority of the investigated farms is equipped with pipe milking machines (72\%), milking machines (20\%) and milking parlours (8\%). The farms use bathtubs for hoofs (20\%), feeding stations (16\%), manure removing machines (10\%), cattle brushes and disinfecting mats $(8 \%)$. In some of the investigated farms, gathering of fodder is mechanical with special gathering units (16\%) while in the remaining farms, this activity is carried out manually (42\%) - (Fig. 3). 
Analysis of technical...

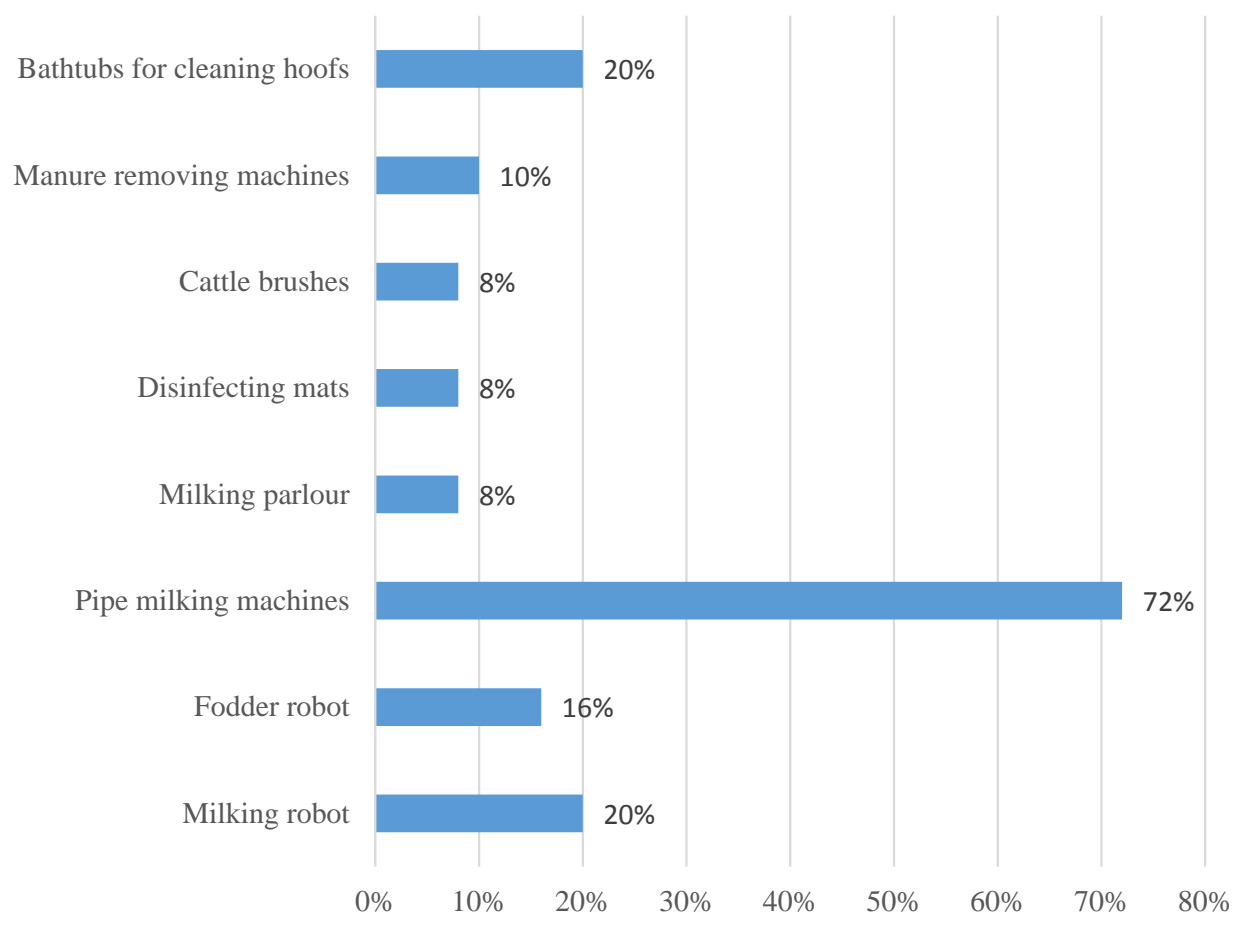

Figure 3. Devices used in dairy cattle breeding

A half of the investigated farmers (50\%) assessed the conditions of their farms as average, a considerable part indicated that it was good (40\%). In the group of the investigated persons there were also such people according to whom a machinery park in a farm is in a bad condition (10\%) - (Fig. 4).

A considerable part of the investigated farmers (44\%) within the last 5 years (20102014) allotted 20-50 thousand PLN for investments related to a machinery park. The following group of the investigated people (26\%) allotted up to 20 thousand PLN for equipping a machinery park. Some of the investigated farmers spent 50 to 100 thousand PLN to facilitate a machinery park. A few indicated no investments in the machinery park. There were also people who invested 100 to 300 thousand PLN (4\%) and more than 500 thousand PLN (2\%) - (Fig. 5). Within 2010-2014 farmers invested at the average 1 thousand to 12 thousand PLN per 1 ha of agricultural land. 
Andrzej Borusiewicz

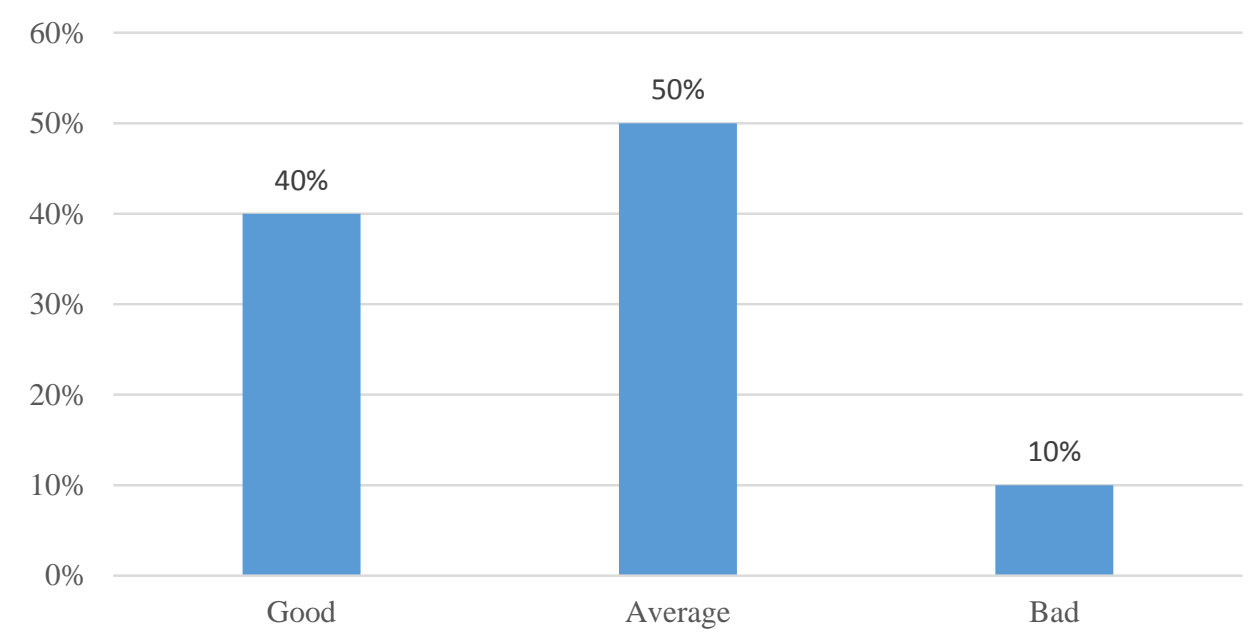

Figure 4. Condition of machinery park according to respondents

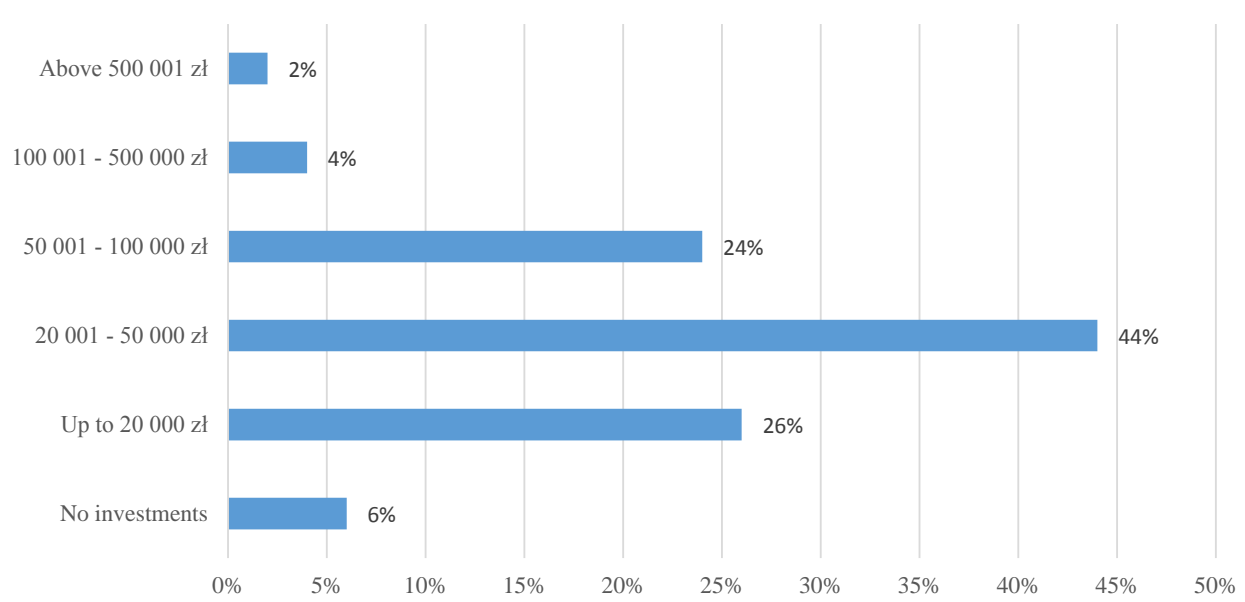

Figure 5. Expenditures for investments related to a machinery park within the last years (2010-2014)

Majority of respondents finances investments related to a machinery park from bank loans (38\%). Some farmers indicated sources of financing such as UE funds (24\%) and leasing (20\%). Often farmers finance investments from their own funds (18\%) - (Fig. 6). 
Analysis of technical...

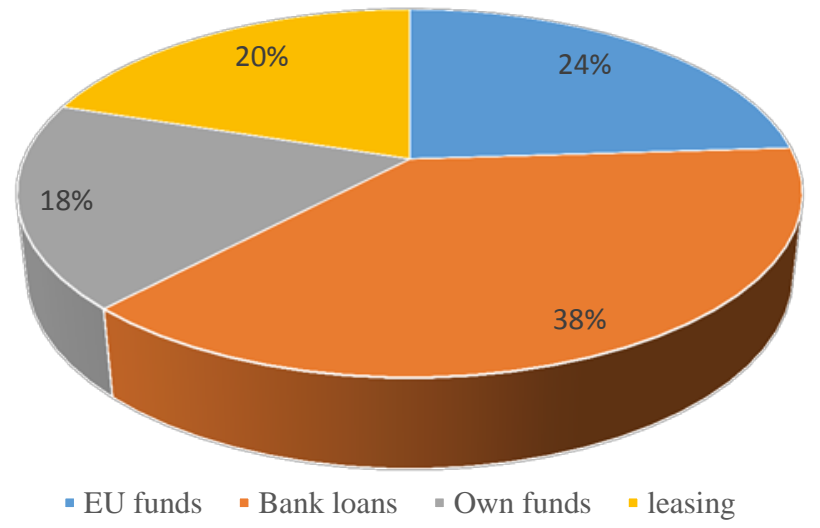

Figure 6. Sources of financing investments related to machinery park

Farmers the most often indicated efficiency (25\%), price (23\%) and access of the service centre (20\%). Some people when choosing equipment for a machinery park takes into account a modern technology (12\%), work ergonomics (6\%), easiness of service $(6 \%)$, technical conditions (5\%) and quality of machines (3\%) - (Fig. 7).

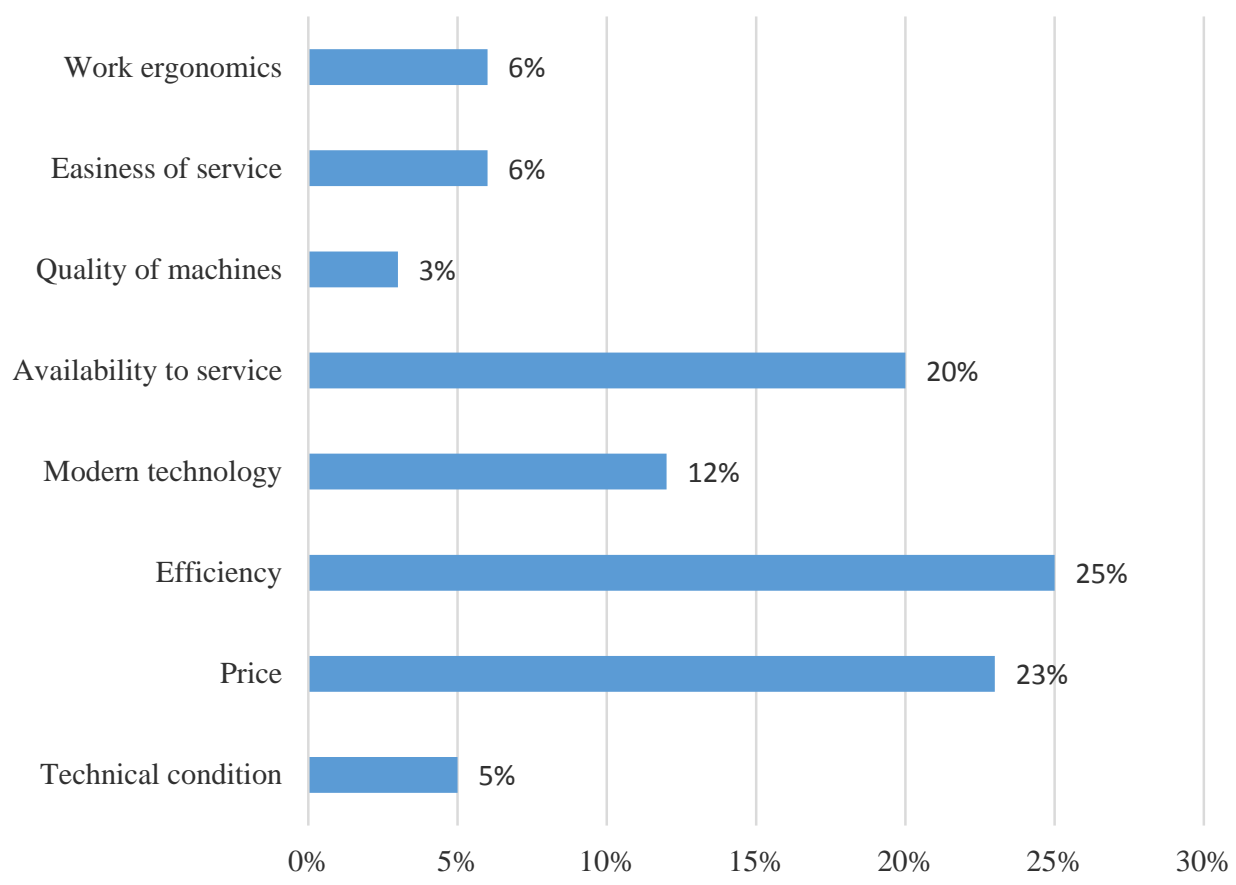

Figure 7. Criteria which determine selection of machines to a farm 


\section{Conclusions}

Dairy farms require both tractors with low and average power for works related to herd management. When planning the number and power of tractors, use of multi-functional machines and devices, one should precisely determine the acreage of agricultural land and trend and size of production of a farm (Kapela, 2012; Kowalski et al., 2006). All investigated farms had farm tractors. Most often these were tractors with the power of 40-60 kW (46\%) and $60 \mathrm{~kW}$ and more (34\%).

As a result of the research it was determined that farmers assessed the condition of their machinery park as average (50\%) or good (40\%). One out of ten farmers claimed that the used machinery park in a farm is in a bad condition. From among the investigated farms, as much as in 69 a pipe milking machine is used (72\%) and in 19 farms milking robots (20\%). The use of milking robots allows control of the entire milking process, analysis of cows' health which is confirmed by Butler et al., (2013) and Rasmussen et al., (2001) in their research. The use of new technologies in a farm influences the production increase as a result of which a farmer may increase farm incomes which is confirmed by Ziętara (2012).

Majority of respondents have allotted PLN 20 to 50 thousand for investments related to enhancement of a machinery park within the recent 5 years. A majority of farms allotted to PLN 20 thousand for development of a machinery park. The investigated group included also farms, which allotted more than PLN 500 thousand for development of a park. Investments in technical production means influence the change of management organization in a farm which specialized in milk production which was confirmed by Hansen and Jervell (2014). A rational development of technique and technology of animal production is preconditioned by a genetic progress, requirements as to animal welfare and products quality and restrictions concerning environmental protection (Romaniuk, 2010)

\section{References}

Auemhammer, H. (2003). The role of mechatronics in product traceability. Club of Bologna. Edizioni Unacoma Service srl, Roma, vol. 13, 112-132.

Butler, D., Holloway, L., Bear, Ch. (2013). The impact of technological change in dairy farming: robotic milking systems and the changing rol of the stockperson. Journal of the Royal Agricultural Society of England, 173, 1-6.

Banasiak, J. (2008). Koncepcja optymalizacji doboru maszyn w rolnictwie. Inżynieria Rolnicza, 4(102), 47-52.

Borusiewicz, A., Kapela, K. (2013). Nowoczesne rozwiązania technologiczno-funkcjonalne stosowane w chowie krów mlecznych na przykładzie wybranych gospodarstw powiatu łomżyńskiego. Inżynieria Rolnicza, 3(146), 41-47.

Cupiał, M. (2010). Informacja a zarządzanie parkiem maszynowym w wybranych gospodarstwach Małopolski. Inżynieria Rolnicza, 3(121), 21-27.

Cupiał, M. (2009). Katalog maszyn i pojazdów rolniczych. Inżynieria Rolnicza, 9(118), 35-41.

Hansen, B. G., Jervell, A.M. (2014). Change management in dairy farming. International Journal of Sociology of Agriculture and Food, 22(1), 23-40.

Jóźwik, K., Misztal, W., Marczuk, A., Kwieciński, A., Fijołek, A. (2012). Dobór środków technicznych do przygotowywania pasz dla bydła mlecznego. Inżynieria Rolnicza, 4(139), 101-108. 
Analysis of technical...

Kapela, K., Woliński, J., Jabłonka, R. (2011). Ocena wyposażenia wybranych gospodarstw specjalizujących się w produkcji mleka w sprzęt rolniczy. Inżynieria Rolnicza, 1(126), 97-10

Kocira, A., Kocira, S. (2010). Typ rolniczy gospodarstw a zasoby pracy i wyposażenie w środki techniczne. Inżynieria Rolnicza, 5(123), 57-62.

Marczuk, A. (2010). Dobór środków technicznych do zadawania pasz w obiektach inwentarskich dla bydła. Inżynieria Rolnicza, 3(121), 119-125.

Marczuk, A., Turski, A. (2009). Wpływ warunków gospodarstwa na dobór maszyn rolniczych do produkcji bydła. Inżynieria Rolnicza, 6(115), 191-197.

Michałek, R., Tomczyk, W. (2002). Problemy eksploatacji maszyn i urządzeń w aspekcie ochrony środowiska. Problemy Inżynierii Rolniczej, 4(10), 5-10.

Muzalewski, A. (2007). Opłacalność użytkowania maszyn nabytych z dotacją. Problemy Inżynierii Rolniczej, 3, 27-33.

Parafiniuk, S. (2006). Nakłady transportowe w badanych gospodarstwach rodzinnych. Inżynieria Rolnicza, 13(88), 377-383.

Pawlak, J. (2010). Uwarunkowania ekonomiczne a mechanizacja. Rocznik Nauk Rolniczych, t. 97, 198-202.

Rasmussen, M. D.; Blom, J. Y.; Nielsen, L. A. H.; Justesen, P. (2001). Udder health of cows milked automatically. Livestock Production Science, 72, 147-156.

Romaniuk, W. (2010). Kierunki zrównoważonego rozwoju technologii i budownictwa w chowie zwierzat. Problemy Inżynierii Rolniczej, 4, 121-128.

Romaniuk, W. (2005). Wymagania formalno-prawne w zakresie standardów technicznotechnologicznych w produkcji zwierzęcej. Inżynieria Rolnicza, 3(63), 23-32.

Romaniuk, W., Łukaszuk, M., Karbowy, A. (2005). Rozwiązania obór pod kątem dobrostanu zwierząt i ochrony środowiska w zakresie produkcji bydła mlecznego i mięsnego. Inżynieria Rolnicza, 4(64), 175-182.

Ziętara, W. (2012). Organizacja i ekonomika produkcji mleka w Polsce, dotychczasowe tendencje i kierunki zmian. Roczniki Nauk Rolniczych, Seria G, t 99, 43-57.

\section{ANALIZA WYPOSAŻENIA TECHNICZNEGO W GOSPODARSTWACH ROLNYCH UKIERUNKOWANYCH NA CHÓW BYDLA MLECZNEGO}

Streszczenie. W pracy dokonano analizy wyposażenia technicznego wybranych gospodarstw specjalizujacych się w chowie bydła mlecznego. Materiał badawczy stanowiły dane pochodzace z badań ankietowych przeprowadzonych w 96 gospodarstwach w 2015 roku. Obszarem badań objęto gospodarstwa położone na terenie gminy Olszewo - Borki w województwie mazowieckim. Instrumentem badawczym był kwestionariusz wywiadu, który składał się z dwóch części. Pierwsza dotyczyła ogólnych informacji o gospodarstwie i jego właścicielu, natomiast druga składała się z ośmiu pytań dotyczących wyposażenia technicznego wykorzystywanego w chowie bydła mlecznego. W wyniku badań ustalono, że rolnicy ocenili stan swojego parku maszynowego jako średni (50\%) lub dobry (40\%). Co dziesiąty badany rolnik, uważał, że wykorzystywany park maszynowy w gospodarstwie jest w złym stanie. Większość badanych w ciągu ostatnich 5 lat na inwestycje związane z rozwojem parku maszynowego przeznaczyła od 20 do 50 tys. zł. Natomiast znaczna część gospodarstw na rozwój parku maszynowego przeznaczyła do 20 tys. zł. W badanej grupie były również gospodarstwa, które przeznaczyły na rozwój parku ponad 500 tys. zł.

Słowa kluczowe: maszyny, wyposażenie techniczne, chów bydła mlecznego 
